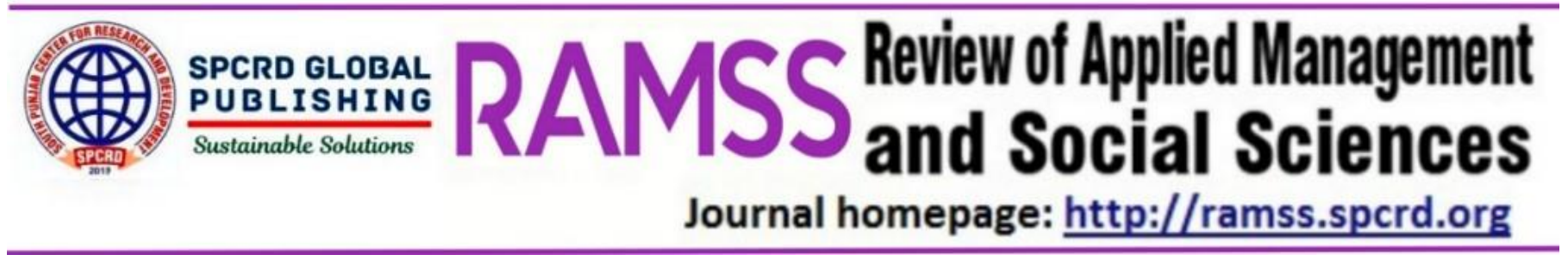

\title{
Institutional Performance and Trade-Led Growth Hypothesis: Evidence from Pakistan
}

\author{
amran Sharif Chaudhry, bajid Ali, cMuhammad Faheem, dFatima Farooq

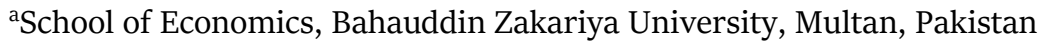 \\ ${ }^{b}$ Faculty of Economics and Management, Universiti Putra, Malaysia \\ ${ }^{c}$ Faculty of Economics and Management, Universiti Putra, Malaysia \\ ${ }^{\mathrm{d} S}$ School of Economics, Bahauddin Zakariya University, Multan, Pakistan \\ Corresponding author's email address: imran@bzu.edu.pk
}

\begin{tabular}{l}
\hline ARTICLE DETAILS \\
\hline History: \\
Accepted: 25 December 2019 \\
Available online: 31December2019 \\
\hline Keywords: \\
Trade Openness, Trade-Led Growth \\
Hypothesis, Institutional \\
Performance, NARDL
\end{tabular}

JEL Classification:

K32, P18, Q56

DOI: $10.47067 /$ ramss.v2i2.15

\section{ABSTRACT}

Economic growth is a researchable debate in the context of trade openness relation in testing trade-led growth hypothesis. This study explores the relation of economic growth with trade openness to test the trade-led growth hypothesis by using a recently developed nonlinear ARDL model over the period 1984-2017 in Pakistan. The results reveal that trade openness affects economic growth differently when it decomposes into positive and negative components, and trade openness decrease has a more impact on economic growth in the presence of labor, capital, FDI and institutional performance as control variables. The mixed relationship of openness-growth in the long-run does not completely verify the trade-led growth and shows non-linear impacts of trade openness on economic growth in Pakistan. The study suggests the policies for government officials and policymakers after unearthing the asymmetric association between trade openness and economic growth that would help to make trade policies for Pakistan.

(C) 2019 The authors. Published by SPCRD Global Publishing. This is an open access article under the Creative Commons Attribution-

NonCommercial 4.0

\section{Introduction}

The role of trade to promote economic growth has been stimulated in many empirical studies since the works of Romer (1990), Grossman and Helpman (1990) and Young (1991). As the trade-led growth hypothesis says that trade works as driver for economic growth, it has been observed that trade openness can boost economic growth by achieving the resource allocation efficiency, giving access to products and services and increasing total factor productivity through information and technology (Freund \&Bolaky, 2008;Valeriani and Paluso, 2011). Countries with increased trade openness are therefore projected to significantly outperform those with decreased trade openness. From this point of view, underdeveloped countries have a lot to benefit from trade with developed countries. Despite these 
anticipated benefits, it is primarily in order to open up and incorporate them into the global market that international organizations and donor governments regularly promote trade openness policies in underdeveloped countries. The failure of the strategy to industrialize import substitution and the findings from empirical studies have also led to these policies, which show that more open economies record higher rates of economic growth (Masoud and Khalid, 2017).

Developing economies have remarkable success in part because of their early policies about trade openness (World Bank, 1993; Stiglitz, 1996). Many underdeveloped economies have enacted trade openness reforms in the late 1970s, including reducing non-tariff barriers and other tariffs of imports and exports. However, few economists claim that increasing openness will be harmful to growth as inflation increases and exchange rate decline (for instance, see Samimi et al. 2012). The openness of trade may hurt growth for the economies specializing in the production of low-quality commodities (Haussman et al., 2007). Countries that export primary goods, for example, are susceptible to trade shocks. Given these opposing opinions, the general consensus is that openness to foreign trade, especially for developing countries, is of benefit to economic growth.

The trade-led growth hypothesis can be separated into two primary hypotheses: export-led growth hypothesis and import-led growth hypothesis. The theory of the export-led growth hypothesis predicts that the expansion of exports is the main component of growth. The growth of the countries may be generated through the expansion of exports along with labor and capital. This form of advocacy is created due to several reasons: first, the growth of exports encourages the use of economies of scale even for developing countries by growing domestic production demand. Secondly, expansion in exports will ease a foreign exchange constraint that encourages importing input to meet domestic requirements, thereby allowing production expansion. Thirdly, export expansion may help the production specialization of products related to exports, which in turn may enhance the productivity level and trigger a general increase in skills in the export sector. Then, capital can be re-allocated to the more efficient export sector from the (relatively) weak non-trade sector.

Changes in productivity can lead to growth in production. Finally, outward-looking trade politics can also provide access to advanced technology, learning from experiences and better management practices that can yield more improvements in efficiency. International trade and development theory, therefore, implies that growth in exports by export-led policy makes a positive contribution to economic growth (Eusuf and Ahmed 2007). The hypothesis of import-led growth indicates that economic growth may be driven basically by the growth of imported goods. Endogenous growth theory suggests that imports of a country can be a path for economic growth in the long-run by providing domestic companies with the accessibility of intermediate and international development factors (Awokuse, 2007).

According to the economic literature, an efficient institutional and legal system will enhance the importance of economic growth (Valeriani and Paluso, 2011). Low productivity can result in inefficient transmission mechanisms and institutions. Better institutional performance supports quality and increases the investment rate, which improves the procedure of capital creation and boosts the growth process (Kirkpat-rick et al., 2006; Ali and Nazar, 2017). Romer (1986) and Lucas (1988) and their supporters have a simplified endogenous growth theory, showing "conditionary" convergence, in which convergence relies on factors linked to institutional performance. According to the assumption of new growth theory, a technology spillover will allow the industrial sector in underdeveloped countries to catch up with their technological frontier as an innovation. The innovations refer to technical 
adaptation, which depends on the institutional arrangements.

North and Thomas (1973) conclude that technological advancements treated as exogenous variables are mainly dependent only on the dominant institutions through their effect on transaction costs and incentives. Institutions promote growth by decreasing the cost of doing business, thereby avoiding the diversion of capital and rent-seeking practices from trying to redirect capital into innovation. A diversion-free society and productive units are completely compensated for production, and all the individual units of the economy do not spend money for the prevention of that diversion.

After approving the first IMF Structural Adjustment Plan in 1988 and joining the World Trade Organization in 1995, Pakistan slowly liberalized its economy. However, in terms of growth and balance of trade, the fruits of openness were not realized in Pakistan (Chaudhary and Ahmed, 2004; Mudassar et al., 2013). It may be because of low institutional performance. The average value of trade openness in Pakistan for 1990-2000 was 32.02 percent, reflecting a minimum of 19.93\% in 1991 and a maximum of $38.91 \%$ in 2000. The new 2018 rating is $28.54 \%$. Institutional performance is the latest engine of economic growth (Chandio et al. 2017). Strong political institutions in Pakistan have a major impact on other social and economic institutions, and reinforcing the political institutions are essential for social and economic growth. Economic growth calculated by real per capita GDP has seen steady growth over the years. However, in the period 2000-2010, comparatively higher growth was observed. During 201016, real income rates were relatively stable and later declined sharply from 2017 due to high inflation. The SPDC (2018) makes a similar assessment, showing that while governments that are subject to authoritarian rule is good for economic growth in Pakistan, but it is not generally as effective in improving institutional performance in a country.

The remaining part of this research is as follows: Section 2 expresses the review of previous literature, and section 3 is reserved for model and methods. Section 4 and section five gives results and conclusion.

\section{Literature Review}

A lot of studies have validated the trade-led growth hypothesis and pointed out the positive linkage between an openness-growth relationship (Freund \&Bolaky, 2008; Shahbaz 2012;Nteegah et al. 2017). On the contrary, few economists disagree the existence of a direct linkage between trade openness and economic growth (e.g. Vlastou, 2010; Polat et al. .2015). The mixed outcomes of previous literature may be accredited to different econometric methodologies, countries and the trade openness proxies. Institutional performance is also a strong indicator of economic growth, and it strengthens the effects of trade openness. So far, very few studies have explored the impact of trade openness and institutional performance on economic growth in Pakistan.

First of all, we present the review of those studies which have examined the hypothesis of tradeled growth in different economies. Awokuse (2008) analyzed the trade-growth nexus in Colombia, Argentina and Peru concerning both imports and exports. After Granger tests and impulse response functions, the causal association between imports and real growth was indicated to be stronger than the relationship between exports and real growth. Shahbaz (2012) validated the trade-led growth hypothesis in Pakistan. Cobb-Douglas function was used, and four proxies of trade transparency have been implemented. The empirical findings have confirmed the existence of growth-driven trade, growth-driven exports and growth-driven imports in Pakistan. 
Gries et al. (2011) have validated the finance-openness-growth nexus for 13 countries of the Caribbean and Latin America region. The findings proposed that trade and financial openness were no pre-conditions for economic development. It was suggested that a balanced policy of financial and trade openness, which considered other important growth factors were more appropriate for these economies. Empirical results from Kim et al. (2012) indicated that opening up trade boosted growth in countries having a low rate of inflation, high-income and services sector-based society. Hossain and Mitra (2013) evaluated the impact of trade openness and FDI on growth in 33 African countries for the year 1974 to 2009. It was found that a rise in trade openness had caused long-term growth. Menyah et al. (2014) validated the trade-led growth hypothesis for 21 countries of Sub-Sahara Africa and pointed out that openness had a negative association with real economic growth.

Nteegah et al. (2017) analyzed a time-series study to evaluate the impact of trade openness policies on the GDP of Nigeria. The outcomes of the ARDL model showed that trade openness policies had a positive effect on GDP in the long-run. Hlalefang and Kolisi (2017) also investigated how trade openness policy affects Ghana and Nigeria's growth by using data from the period 1980 to 2016 . The results discovered that open trade policies had a direct effect on Ghana's growth rate, while there was a negative association between trade openness and growth in the case of Nigeria. In addition, Iheanacho (2017) analyzed the validation of the trade-led growth hypothesis for the emerging economy of Nigeria using the data from 1981 to 2014. The research employed two trade liberalization initiatives to build up the openness index, while initiatives of financial growth were utilized to create a financial development index. The findings demonstrated that trade openness had a negative and substantial long-term effect on growth, and hence trade-led growth was not validated for Nigeria.The outcome of the other variable, such as employed labor force, financial development, and gross capital formation, showed that none of them had a major effect on Nigeria's growth.

Over the period 1960 to 2015, Masoud and Khalid (2017) evaluated the openness-growth nexus in China. The results of the analysis indicated that the association of openness and growth was positive in the long-run. Similarly, Ahmad et al. (2017) addressed the association between trade openness and GDP growth in Pakistan. Aggregate demand and supply models and their estimates were based on a simple ordinary least square (OLS) technique. Trade openness had been observed to have a reversed impact on GDP growth. Mishaelight and Khobai (2018) have integrated FDI and rate of employment as an additional variable to form a multivariate system to examine the trade-growth relationship in Switzerland and validated the trade-led growth hypothesis.

North (1990) argued that institutions were characterized as the rule of the game in the economic system of the human constraints that make the interaction between the people. It was defined that rules of the game could be established by formal institutions like legislation, rules and regulations or informal institutions that were equated to social capital (Putnam at al. 1993) and culture (Tabellini, 2005). Many institutions had minimized processing costs and thereby generate creativity and efficiency, while other institutional characteristics impeded knowledge flow, increased information costs and eroded information benefits, and restricted business activity, e.g., government, police and/or court corruption, the rule of law, democracy, the tax system, etc., were institutions which stunt economic growth (Sachs \& Warner, 1995, Barro, 1997, 2000; Meon\&seckat, 2004; Kaufmann et al., 2005).

Jalilian et al. (2007) highlighted the function of institutional ability to regulate the compensation of cross-country changes in the growth of a country. He found evidence that institutional factors were closely linked to the overall productivity factor. Countries having stronger institutions and governance 
efficiency had higher productivity growth. Regarding the causal effect of institutional quality and economic efficiency, the empirical studies by Acemoglu et al. (2000), Rodrik et al. (2004) and Kauffman et al. (2005) showed that good institutional performance leads to the high level of GDP. It was proposed by Kauffman et al. (2005) that one standard deviation increase in good governance caused 2 to 3 times increase in income rates in the long-run.

Manystudies have attempted to study institutions in both Pakistan and South Asia. Ul Haq (2000) and Ahmed (2001) hadshownthat institutions in South Asia seemed to be a big issue. Hussain (1999) saidthatinstitutional collapse hadcontributed to weakgovernance, leading to ad-hoc policymaking in Pakistan. Instability and volatilityhaddiscouraged the investment in the long-run and fostered lobbying, misuse of power, corruption and leading to dissatisfaction and dysfunctionalbehaviour. According to Sarwar et al. (2013) and Kacho and Dahmardeh (2017), the two main factors for economicgrowthwerefinancialdevelopment and institutional performance. A solidinstitutionalframeworkfosteredeconomicgrowth. To explore the connectionbetweeninstitutional performance and innovation, Tebaldi and Elmslie (2013) employed cross-country data and instrumental variable methodology. It wasshownthat the institutional structure explained production significantly, and human capital wasnecessary to form long-term institutions.

For the period 1990-2013, Asghar et al. (2015) used panel data for 13 emerging Asian economies to identify the impact of institutional performance on economicgrowth. It wasindicatedthat the efficiency of the institutions had a direct effect on economicgrowth. Siyakiya (2017), using data of 28 countries of Europe, checked the impact of institutions and itssub-indicators (effectiveness of governance, politicalstability, control of corruption, the rule of law, accountability and regulationquality) on economic performance measured by per capita gross value added. System GMM wasapplied, and the resultsindicated a positive relationshipbetween institutions and economic performance. A ten-unit improvement in institutionalqualitywaspredicted to enhance per capita gross value added by 1.33 units.

\section{Methodology}

Data for this study is obtained from different sources. Data for real GDP, FDI and trade openness is obtained from World Development Indicators (WDI), The data for physical capital stock and the employed labor force is collected from Penn's World Table 9.o. The index for institutional performance is collected from International Country Risk Guide (ICRG) which is made up from 7 indicators of institutional performance i.e. (stability of government, socio-economic conditions, control of corruption, law and order, democratic accountability, bureaucracy quality and investment profile). We have applied principal component analysis (PCA) on STATA to construct institutional performance index (INP). The study covers the data over the period 1984-2017 for Pakistan.

Different econometric methodologies have been used in the previous literature to show the association between trade openness and economic growth in a single country or group of countries analysis. The existing literature uses different econometric methodologies to show the connection of various macroeconomic variables (Faheem et al., 2014; Aftab et al., 2015; Anwar et al., 2016). This study applied a unique methodology recently developed in the extension of ARDL by Shin, Yu, and Greenwood-Nimmo (2014). This methodology helps to understand the asymmetric effect of one variable to the others due to its novel properties and advantages over traditional estimation techniques. The first and foremost advantage of this method is free from same order restriction and valid in case of mixed order of cointegration like I(1) or mixture I(o) and I(1) order of integration. Secondly, it is not helpful in the case of I(2) order of integration. Thirdly, this method provides short-run and long-run 
components at a time that covers the endogeneity and serial correlation problems (Pesaran and Shin, 1999). This method may be applied even in the case of a small sample size (Pesaran et al. 2001).

Based on the theoretical framework, economic growth express as follows:

$$
\mathrm{GDP}=\mathrm{f}(\mathrm{TO}, \mathrm{L}, \mathrm{K}, \mathrm{FDI}, \mathrm{INP})
$$

To achieve study objective firstly following specification can be used under this methodology:

$$
G D P_{t}=\alpha_{0}+\alpha_{1} T O_{t}+\alpha_{2} L_{t}+\alpha_{3} K_{t}+\alpha_{4} F D I_{t}+\alpha_{5} I N P_{t}+\mu_{t}
$$

Where GDP, TO, L, K, FDI and INP show real GDP, trade openness, employed labor force, physical capital stock, foreign direct investment and institutional performance, respectively. Each variable is expressed in log form except INP. Additionally, to estimate the long-run parameter, $\alpha=\left(\alpha_{0}\right.$, $\alpha_{1}, \alpha_{2}, \alpha_{3}, \alpha_{4}$ and $\alpha_{5}$ ) indicates a vector.

The above equation (2) can be written in formulation of ARDL bounds by following specification:

$$
\begin{aligned}
& \Delta G D P_{t}=\alpha_{0}+\sum_{i=1}^{n 1} a_{1 i} \Delta G D P_{t-1}+\sum_{i=0}^{n 2} \alpha_{2 i} \Delta T O_{t-i}+\sum_{i=0}^{n 3} \alpha_{3 i} \Delta L_{t-i}+\sum_{i=0}^{n 4} \alpha_{4 i} \Delta K_{t-i}+\sum_{i=0}^{n 5} \alpha_{5 i} \Delta F D I_{t-i}+\sum_{i=0}^{n 6} I N P_{t-i} \\
& +\beta_{1} G D P+\beta_{2} T O_{t-1}+\beta_{3} L_{t-1}+\beta_{4} K_{t-1}+\beta_{5} F D I_{t-1}+\beta_{6} I N P_{t-1}+\mu_{t}
\end{aligned}
$$

Where the concerned variable first difference operator and deterministic drift parameter denoted by $\Delta$ and $\alpha_{0}$

The estimation of unrestricted error correction model from above equation as follows:

$$
\begin{aligned}
& \Delta G D P_{t}=\alpha_{0}+\sum_{i=1}^{n 1} a_{1} \Delta G D P_{t-i}+\sum_{i=0}^{n 2} \alpha_{2} \Delta T O_{t-i}+\sum_{i=0}^{n 3} \alpha_{3} \Delta L_{t-i}+\sum_{i=0}^{n 4} \alpha_{4} \Delta K_{t-i}+\sum_{i=0}^{n 5} \alpha_{5} \Delta F D I_{t-i}+\sum_{i=0}^{n 6} \alpha_{6} \Delta I N P_{t-i} \\
& +\lambda E C T-1+v t_{t}
\end{aligned}
$$

Where, $\lambda$ denotes a parameter for the speed of adjustment and estimated model's residuals expresses by ECT. Moreover, to show the asymmetric behavior of trade on economic growth that expresses by nonlinear ARDL model in which trade is decomposed into positive and negative parts as follows:

$$
G D P_{t}=\beta_{1}+\beta_{2}^{+} T O^{+}+\beta_{2}^{-} T O_{t}^{-}+\beta_{3} X_{t}+\mu_{t}
$$

On the basis of nonlinear model (equation (5), increase in trade openness effect on economic growth expreeses by $\beta_{2}{ }^{+}$in equation (6) and expected to be positive while in the equation (7) $\beta_{2}{ }^{-}$denotes negative trade openness effect on economic growth in long run.

$$
\begin{aligned}
& \beta_{2}{ }^{+} \boldsymbol{T O _ { t }}{ }_{t}^{+}=\sum_{j=1}^{t} \Delta \boldsymbol{T} O_{j}^{+}=\sum_{j=1}^{t} \max \left(\Delta \boldsymbol{T} O_{j}, 0\right) \\
& \beta_{2}{ }^{-} T O_{t}^{-}=\sum_{j=1}^{t} \Delta T O_{j}^{-}=\sum_{j=1}^{t} \max \left(\Delta T O_{j}, 0\right)
\end{aligned}
$$


In an extension of ARDL Shin, Yu, and Greenwood-Nimmo (2014) developed NARDL setting as:

$$
\begin{aligned}
& \Delta G D P_{t}=\alpha_{0}+\sum_{i=1}^{n 1} a_{1 i} \Delta G D P_{t-1}+\sum_{i=0}^{n 2} \alpha^{+}{ }_{2 i} \Delta T O^{+}{ }_{t-i}+\sum_{i=0}^{n 2} \alpha^{-}{ }_{2 i} \Delta T O^{-}{ }_{t-i}+\sum_{i=0}^{n 3} \alpha_{3 i} \Delta L_{t-i}+\sum_{i=0}^{n 4} \alpha_{4 i} \Delta K_{t-i}+\sum_{i=0}^{n 5} \alpha_{5 i} \Delta F D I_{t-i}+\sum_{i=0}^{n 6} \alpha_{6 i} \Delta I N P_{t-i} \\
& +\beta_{1} G D P_{t-1}+\beta_{2}^{+} T O_{t-1}{ }^{+}+\beta^{-}{ }_{2} T O^{-}{ }_{t-1}+\beta_{3} L_{t-1}+\beta_{4} K_{t-1}+\beta_{5} F D I_{t-1}+\beta_{6} I N P_{t-1}+\mu_{t}
\end{aligned}
$$

For the measurement of asymmetry, the following hypothesis is used as $\beta_{2}{ }^{+}$and $\beta_{2}{ }^{-}, \alpha_{2}{ }^{+}$and $\alpha_{2}{ }^{-}$, respectively:

\section{Results and Discussion}

$$
\begin{aligned}
& \mathrm{H}_{\mathrm{o}}: \beta_{2}{ }^{+}=\beta_{2}{ }^{-}=\mathrm{O} \\
& H_{0}: \sum_{i=0}^{n 2} \alpha^{+}{ }_{2 i}=\sum_{i=0}^{n 2} \alpha^{-}{ }_{2 i} \\
& \text { for all } \mathrm{i}=0, \ldots, \mathrm{n}
\end{aligned}
$$

The following table expresses the outcome of the ADF, and the Phillips Perron test confirms that GDP, trade openness (TO), labor (L), capital (K), FDI and institutional performance are non-stationary at the level and stationary after converted to the first difference.

\section{Table 1: ADF and PP Unit Root tests}

\begin{tabular}{cllll}
\hline LevelFirst Difference & \multicolumn{3}{c}{ ADFPP } \\
\hline Variable & \multicolumn{1}{c}{ ADFPP } & & \\
\cline { 2 - 5 } GDP & 2.07 & 2.10 & $-3.10^{* *}$ & $-3.23^{* *}$ \\
TO & -2.23 & -2.21 & $-6.22^{* * *}$ & $-6.22^{* * *}$ \\
L & 2.58 & 3.82 & $-5.32^{* * *}$ & $-5.33^{* * *}$ \\
K & 2.62 & 3.11 & $5.89^{* *}$ & $5.97^{* *}$ \\
FDI & -2.78 & -1.91 & $-3 . .80^{* * *}$ & $-3.78^{* * *}$ \\
INP & -2.27 & -4.51 & $-7.64^{* * *}$ & $-7.41^{* * *}$ \\
\hline
\end{tabular}

Note: $* * *, * *$ express significant at $1 \%$ and $5 \%$.

The following table shows the cointegration F-statistics results for linear and nonlinear model and the express absence of cointegration in the linear model. The results of the nonlinear model show cointegration as calculated F-statistics exceed upper bound.

Table 2 ARDL Bound Test for Cointegration

\begin{tabular}{lllll}
\hline & F-Statistic & $\begin{array}{l}\text { Lower } \\
\text { Bound 95\% }\end{array}$ & $\begin{array}{l}\text { Upper } \\
\text { Bound95\% }\end{array}$ & Decision \\
\hline $\begin{array}{l}\text { Linear } \\
\text { ARDL }\end{array}$ & 1.36 & 2.61 & 3.35 & $\begin{array}{l}\text { No- } \\
\text { Cointegration } \\
\text { Asymmetric } \\
\text { ARDL }\end{array}$ \\
\hline
\end{tabular}

The below table 3 expresses the long run results and diagnostic test. The findings of the diagnostic test express that model is free from heteroskedasticity, stability and autocorrelation problems. Moreover, to test stability study shows the CUSUM and CUSUM of squares test results that express the stability of the model. The overall picture of the data and the variable correlation matrix is 
given in the table ( see appendix).

In the long run, the findings show trade openness has different effects on economic growth when we decompose it into positive and negative components. In other words, results explain that a one percent increment in trade openness is associated with 0.771 percent enhancement in economic growth, while a one percent decrease in trade openness is associated to a 1.423 percent increase in economic growth, but the impact is higher when trade openness increase. The rest of the variables, FDI, capital, and institutional performance, are significant while labor is insignificant. These mixed results do not completely validate the trade-led growth hypothesis in Pakistan. It shows the non-linear effects of trade openness on economic growth. This behaviour of trade openness and growth is may be due to the influence of other variables, i.e. labor force, gross capital formation and institutional performance. The findings are similar to the following studies in various regions, i.e. Freund \&Bolaky (2008), Vlastou (2010), Shahbaz (2012), Ali et al. (2012), Menyah et al. (2014), Polat et al. (2015) andNteegah et al. (2017).

\section{Table 3 ARDL Long-Run Estimation and Diagnostic Checks}

\begin{tabular}{|c|c|c|c|}
\hline Regressors & Coefficients & Standard error & t-ratio (Prob.) \\
\hline $\mathrm{TO}^{+}$ & 0.771 & 0.389 & $1.982 * *(0.048)$ \\
\hline $\mathrm{TO}^{-}$ & -1.423 & 0.417 & $-3.411 * * *(0.002)$ \\
\hline $\mathrm{L}$ & 0.943 & 0.652 & $1.448(0.160)$ \\
\hline K & -0.895 & 0.416 & $-2.149^{* *}(0.041)$ \\
\hline FDI & 0.072 & 0.027 & $2.660^{* *}(0.013)$ \\
\hline INP & 0.177 & 0.069 & $2.563^{* *}(0.017)$ \\
\hline Intercept & 33.646 & 4.419 & $7.568 * * *(0.000)$ \\
\hline R Square & 0.999 & Serial Correlation & $2.552(0.092)$ \\
\hline DW Stat & 1.986 & Functional Form & $1.560(0.224)$ \\
\hline Normality & $0.165(0.920)$ & Heteroscedasticity & $2.024(0.112)$ \\
\hline $\mathrm{W}_{\mathrm{LR}}$ & $4.708(0.039)$ & $\mathrm{W}_{\mathrm{SR}}$ & $5.445(0.028)$ \\
\hline
\end{tabular}

The findings in short-run are quite impressive that is trade openness negative changes are more efficient as positive changes in trade balance that showing one percent decrease in trade openness with a 0.255 percent increment in economic growth, while one percent raise in trade openness associated with 0.138 percent increase in economic growth in the short-run. The other variables FDI, capital and institutional performance, are significant. The value of the ECT term is negative and significant that shows the long-run convergence. 
Table 4: ARDL Short -Run Coefficients

\begin{tabular}{lllc}
\hline Regressors & Coefficients & Standard error & t-ratio [prob.] \\
\hline $\mathrm{D}\left(\mathrm{TO}^{+}\right)$ & 0.138 & 0.062 & $2.230^{* *}(0.035)$ \\
$\mathrm{D}\left(\mathrm{TO}^{-}\right)$ & -0.255 & 0.064 & $-3.970^{* * *}(0.000)$ \\
$\mathrm{D}(\mathrm{L})$ & 0.169 & 0.103 & $1.643(0.113)$ \\
$\mathrm{D}(\mathrm{K})$ & -0.161 & 0.047 & $-3.443^{* * *}(0.002)$ \\
$\mathrm{D}(\mathrm{FDI})$ & 0.013 & 0.005 & $2.423^{* *}(0.023)$ \\
$\mathrm{D}(\mathrm{INP})$ & 0.032 & 0.007 & $4.718^{* * *}(0.000)$ \\
ECT & -0.179 & 0.053 & $-3.411(0.002)$ \\
\hline
\end{tabular}

Note: ${ }^{*},{ }^{* *},{ }^{* *}$ shows significance level at $10 \%, 5 \%$ and $1 \%$ respectively.

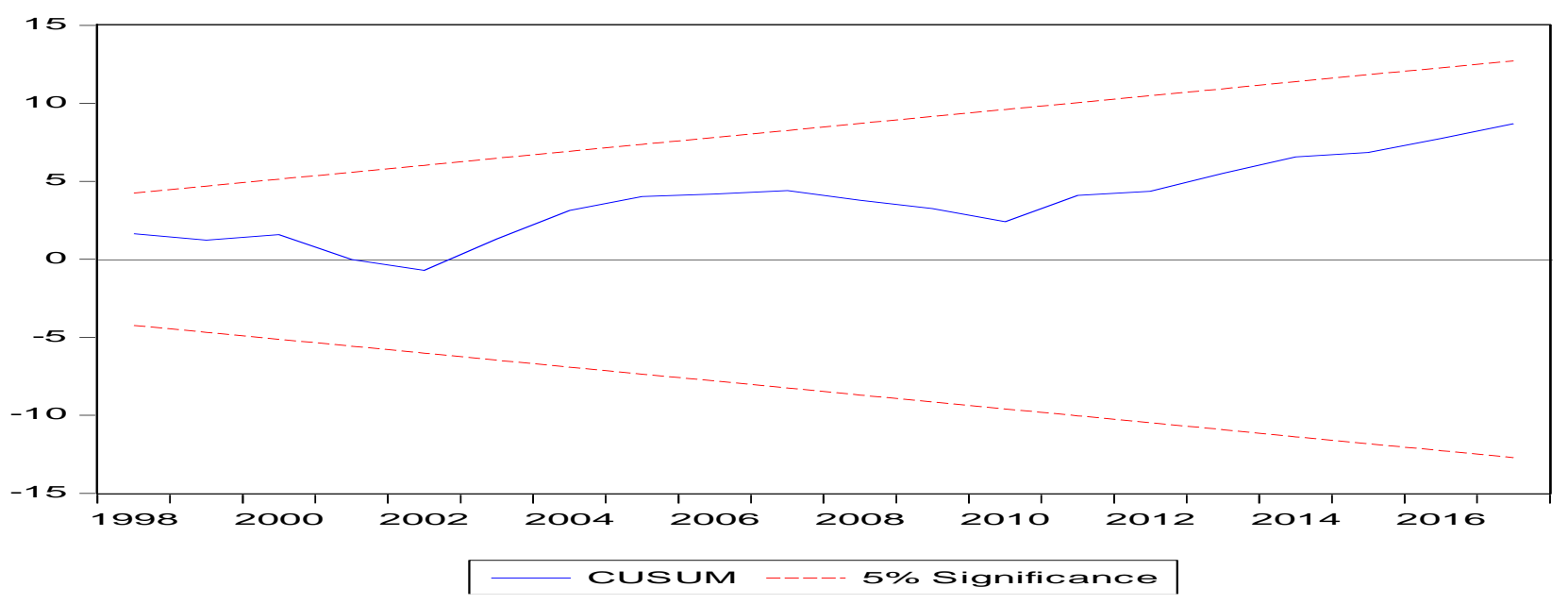

Figure 1. CUSUM Test.

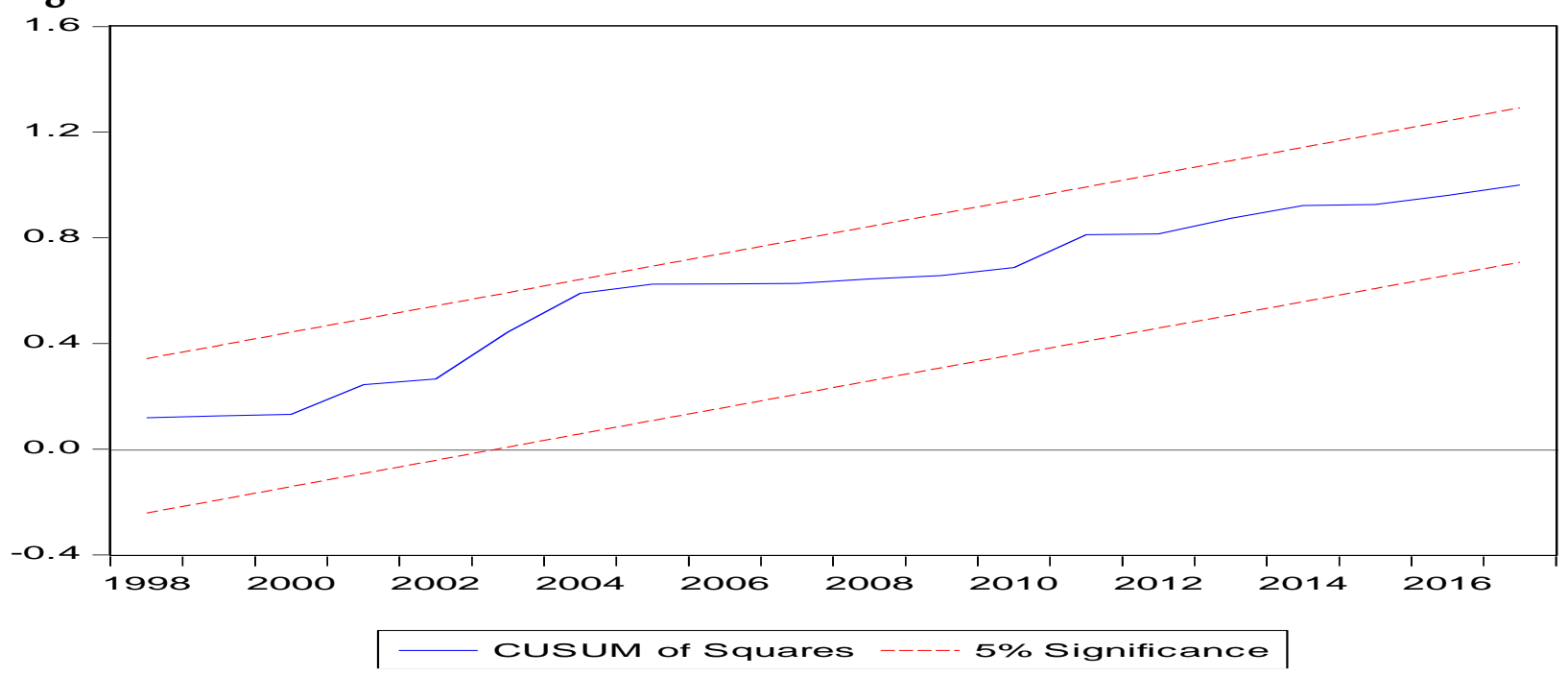

Figure 2. CUSUM of Square Test. 
To check the asymmetry of trade openness effect on economic growth, the study employed Wald test, and results are reported in the above table 3, which are in favour of asymmetry in the long run and short run. Additionally, asymmetry is presented through the graphical by following a cumulative dynamic multiplier graph.

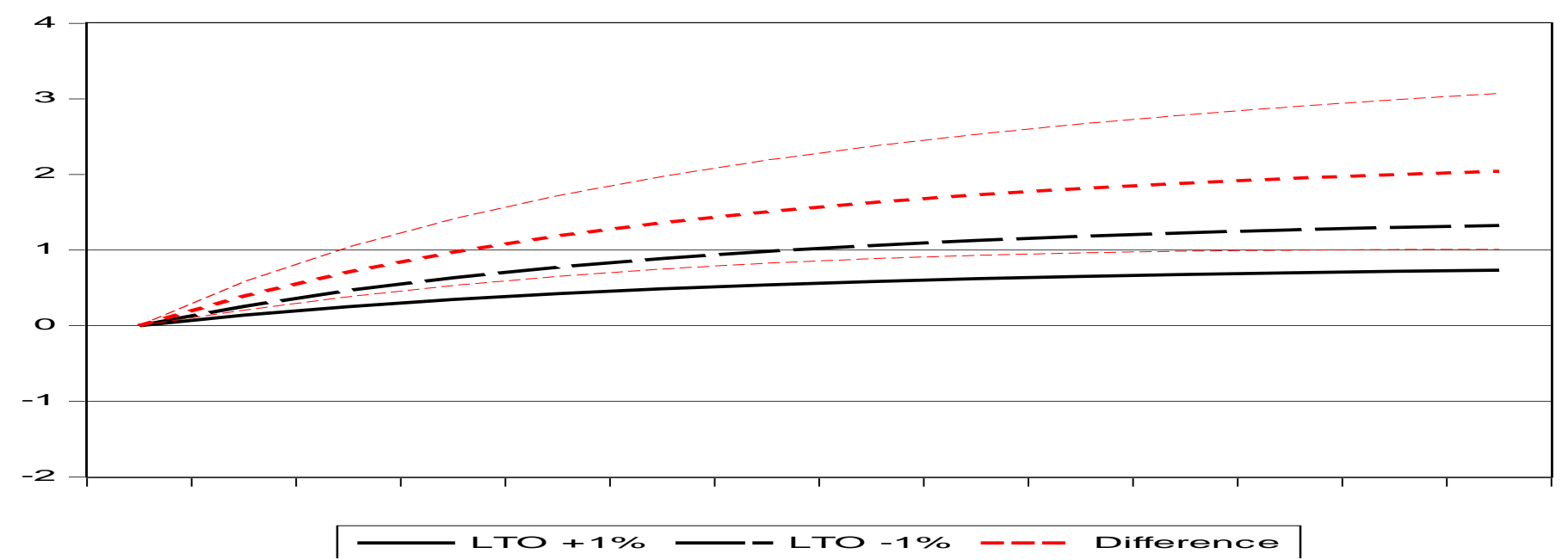

Figure 3 Dynamic Multiplier Graph.

\section{Conclusion}

This study expresses the effect of trade openness on economic growth in Pakistan for the year 19842017. The recently developed methodology NARDL model is used to test the trade-led growth hypothesis. The findings show that trade openness affects economic growth differently when it decomposes into positive and negative changes, and trade openness decrease has a more impact on growth in Pakistan. The mixed impact of trade openness on economic growth in the long-run does not completely validate the trade-led growth hypothesis in Pakistan. It shows the non-linear effects of trade openness on economic growth.The other variables, FDI, capital and institutional performance, have a significant effect on economic growth. On behalf of results, the study recommends the policies for government officials and policymakers after unearthing the asymmetric relationship between trade openness with an economic growth that would help make trade policies for Pakistan.

\section{APPENDIX}

Descriptive Statistics and Correlation

\begin{tabular}{lllllll}
\hline & GDP & TO & L & K & FDI & INP \\
\hline Mean & $1.31 \mathrm{E}+11$ & 0.325381 & 38.97084 & 788377.9 & 1.009743 & 1.964461 \\
Median & $1.19 \mathrm{E}+11$ & 0.325741 & 35.72381 & 552514.9 & 0.728144 & 2.000000 \\
Maximum & $2.4 \mathrm{OE}+11$ & 0.391865 & 60.87498 & 1945860. & 3.668323 & 3.000000 \\
Minimum & $5 \cdot 59 \mathrm{E}+10$ & 0.255820 & 24.66994 & 186379.0 & 0.178192 & 1.000000 \\
Std. Dev. & $5.24 \mathrm{E}+10$ & 0.035564 & 11.14301 & 573518.2 & 0.825550 & 0.361227 \\
Skewness & 0.420062 & -0.100286 & 0.504803 & 0.693713 & 2.025531 & 0.476523 \\
Kurtosis & 2.054943 & 1.973736 & 1.951204 & 2.008950 & 6.393319 & 5.780254 \\
Jarque-Bera & 2.265166 & 1.549049 & 3.002308 & 4.118437 & 39.56145 & 12.23732 \\
Probability & 0.322200 & 0.460923 & 0.222873 & 0.127554 & 0.000000 & 0.002201 \\
Sum & $4.45 \mathrm{E}+12$ & 11.06297 & 1325.008 & 26804847 & 34.33125 & 66.79167 \\
Sum Sq. Dev. & $9.06 \mathrm{E}+22$ & 0.041738 & 4097.497 & $1.09 \mathrm{E}+13$ & 22.49056 & 4.306015
\end{tabular}




\begin{tabular}{lllllll}
\hline Observations & 34 & 34 & 34 & 34 & 34 & 34 \\
GDP & 1 & -0.5790 & 0.9947 & 0.9835 & 0.3136 & -0.0051 \\
TO & & 1 & -0.5897 & -0.5760 & 0.3011 & -0.2034 \\
L & & 1 & 0.9929 & 0.2648 & 0.0085 \\
K & & & 1 & 0.2258 & -0.0161 \\
FDI & & & & 1 & -0.0905 \\
INP & & & & & & 1 \\
\hline
\end{tabular}

\section{References}

Afza, T., \& Adnan, S. M. (2007). Determinants of corporate cash holdings: A case study of Pakistan. Proceedings of Singapore Economic Review Conference (SERC) 2007, August 01-04, Organized by Singapore Economics Review and the University of Manchester (Brooks World Poverty Institute), Singapore 164-165.

Assfaw, A. M. (2019). Firm-Specific and Macroeconomic Determinants of Banks Liquidity: Empirical Investigation from Ethiopian Private Commercial Banks. Journal of Accounting, Finance and Auditing Studies, 5(2), 123-145.

Attari, M. A., \& Raza, K. (2012). The optimal relationship of cash conversion cycle with firm size and profitability. International Journal of Academic Research in Business and Social Sciences, 2(4), 189.

Acemoglu, D., Johnson, S., \& Robinson, J. A. (2005). Institutions as a fundamental cause of long-run growth. Handbook of economic growth, 1, 385-472.

Aftab, M. R., Rehman, M., Abdul, C., \& Faheem, M. (2015). Food Prices and its Impact on Poverty in Pakistan. Pakistan Journal of Social Sciences (PJSS), 35(2).

Ahmad, W., Mir, S., Siddique, M., \& Rehman, H. U. (2017). Trade openness and economic growth: empirical evidence from Pakistan. Journal of Economic Info, 4(1), 1-3.

Ahmed, S. (2001). Poverty Reduction and Governance in South Asia. Mahbub ul Haq Human Development Review, 1(1).

Ali, S., Chaudhry, I. S., \& Farooq, F. (2012). Human capital formation and economic growth in Pakistan. Pakistan Journal of Social Sciences, 32(1), 229-240.

Ali, S., \&Nazar, R. (2017). Impact of Foreign Capital Inflows and Money Supply on Exchange Rate: A Case Study of Pakistan. Review of Economics and Development Studies, 3(1), 83-90.

Anwar, Y., Farooq, F., Ullah, S., \& Faheem, M. (2016). Impact of Financial Globalization on Human Capital: Evidence from Pakistan. Pakistan Journal of Social Sciences $\quad$ (PJSS), 36(2).

Awokuse, T. O. (2007). Causality between exports, imports, and economic growth: Evidence from transition economies. Economics letters, 94(3), 389-39.

Awokuse, T. O. (2008). Trade openness and economic growth: is growth export-led or importled?. Applied economics, 40(2), 161-173.

Barro, R. J. (1997). Determinants of economic growth: a cross-country empirical study. Lionel Robbins Lectures.

Barro, R. J. (2000). Inequality and growth in a panel of countries. Journal of Economic growth, $5(1), 5-32$.

Chandio, A. A., Rehman, A., Jiang, Y., \& Joyo, M. A. (2017). Financial development, trade openness and economic growth in Pakistan: A granger causality approach. International Journal of Advanced and Applied Sciences, 4(4), 73-80.

Eusuf, M. A., \& Ahmed, M. (2007). Causality between export and growth: Evidence from South 
Asian Countries.

Faheem, M., Fakher, A., \& Ali, S. (2014). Inequality and Economic Growth: An Overview. International Journal of Physical and Social Sciences, 4(9), 159-169.

Freund, C., \&Bolaky, B. (2008). Trade, regulations, and income. Journal of Development Economics, 87, 309-321.

Gries, T., Kraft, M., \&Meierrieks, D. (2011). Financial deepening, trade openness and economic growth in Latin America and the Caribbean. Applied Economics, 43(30), 4729-4739.

Grossman, G. M., \&Helpman, E. (1990). Comparative advantage and long-run growth. American

Economic Review, 80, 796-815.

Haussmann, R., Hwang, J., \& Rodrik, D. (2007). What you export matters. Journal of Economic Growth, 12, 1-25.

Hlalefang, K. N., \&Kolisi, C. M. (2017). Long run relationship between trade openness and economic growth in Ghana and Nigeria. Munich Personal RePEc Archive, 81317.

Hossain, M. S., \& Mitra, R. (2013). The determinants of economic growth in Africa: a dynamic causality and panel cointegration analysis. Economic Analysis and Policy, 43(2), 217.

Hussain, I. (1999). Pakistan: The Economy of an Elitist State. Karachi: Oxford University Press.

Iheanacho, E. (2017). ARDL Approach to Trade Libralisation and Economic Growth in the Developing Country: Evidence from Nigeria. African Research Review, 11(2), 138-159.

Jalilian, H., Kirkpatrick, C., \& Parker, D. (2007). The impact of regulation on economic growth in developing countries: A cross-country analysis. World development, 35(1), 87-103.

Kacho, A. \&Dahmardeh, N. (2017). The effects of financial development and institutional quality on economic growth with the dynamic panel data generalized moment method: Evidence from the organization for economical cooperation and development countries. International Journal of Economics and Financial Issues. 7(3), 461-467.

Kaufmann, D., Kraay, A., \&Mastruzzi, M. (2005). Governance matters IV: governance indicators for 1996-2004. The World Bank.

Kim, D. H., Lin, S. C., \& Suen, Y. B. (2012). The simultaneous evolution of economic growth, financial development, and trade openness. The Journal of International Trade \& Economic

Development, 21(4), 513-537.

Kirkpatrick, C., Parker, D. \& Zhang, Y. (2006). Foreign direct investment in infrastructure: Does regulation make a difference? Transnational Corporations, 15(1). 143-171.

Masoud, A. K., \& Khalid, H. A. (2017). Investigation of the Relationship between Trade Openness and Economic Growth in the Case Of China. International Journal of Research -Granthaalayah, 5(7), 199-213.

Menyah, K., Nazlioglu, S., \&Wolde-Rufael, Y. (2014). Financial development, trade openness and economic growth in African countries: New insights from a panel causality approach. Economic Modelling, 37, 386-394.

Méon, P-G., \&Sekkat, K. (2004). Does the Quality of Institutions Limit the MENA's Integration in the World Economy? The World Economy, 27, 1475-1498.

Mishaelight, C., \&Hlalefang, K. (2018). The Impact of Trade Liberalization on Economic Growth in Switzerland. Munich Personal RePEc Archive, 89884.

Mudassar, K., Fakher, A., Ali, S., \& Sarwar, F. (2013). Validation of twin deficits hypothesis: a case study of Pakistan. Universal Journal of Management and Social Sciences, 3(10), 33- 47.

North D. C. (1990). Institutions, institutional change and economic performance. Cambridge, MA: Cambridge University Press, New York. https://doi.org/10.1017/СBO9780511808678

Nteegah, A., Nelson, M., \&Owede, M. (2017). Trade liberalization and economic growth in Nigeria. International Journal of Social Science and Economics Invention, 3(05), 474-to. 
Pesaran H, Shin Y (1999) An autoregressive distributed lag modeling approach to cointegration analysis. In: Strom S (ed) Econometrics and economic theory in 2oth century: the Ragnar-Frisch centennial symposium. Cambridge University Press, Cambridge.

Pesaran, M. H., Shin, Y., \& Smith, R. J. (2001). Bounds testing approaches to the analysis of level relationships. Journal of applied econometrics, 16(3), 289-326.

Polat, A., Shahbaz, M., Rehman, I. U., \&Satti, S. L. (2015). Revisiting linkages between financial development, trade openness and economic growth in South Africa: Fresh evidence from combined cointegration test. Quality and Quantity, 49, 785-803.

Putnam, R. D., Leonardi, R., \&Nanetti, R. Y. (1993). Making Democracy Work: Civic Traditions in Modern Italy. Princeton: Princeton University Press.

Rodrik, D., Subramanian, A., \&Trebbi, F. (2004). Institutions rule: the primacy of institutions over geography and integration in economic development. Journal of economic growth, 9(2), 131-165.

Romer, P. M. (1990). Endogenous technological change. Journal of Political Economy, 98, 71- 102.

Sachs, J. D., \& Warner, A. M. (1995). Economic reform and the process of global integration. Brookings Paper in Economic Activities, 1, 1-95. https://doi.org/10.2307/2534573

Samimi,J. A., Ghaderi, S., Hosseinzadeh, R., \&Nademi, Y. (2012). Openness and inflation: New empirical panel data evidence. Economics Letters, 117, 573-57.

Sarwar, F., Fakher, A., Ali, S., \& Mudassar, K. (2013). Human capital, population and economic growth: A cointegration approach. Universal Journal Of Management And Social Sciences, 3(10), 20-32.

Shahbaz, M. (2012). Does trade openness affect long run growth? Cointegration, causality and forecast error variance decomposition tests for Pakistan. Economic Modelling, 29(6), 2325-2339.

Shin, Y., Yu, B., \& Greenwood-Nimmo, M. (2014). Modelling asymmetric cointegration and dynamic multipliers in a nonlinear ARDL framework. In Festschrift in honor of Peter Schmidt (pp. 281-314). Springer, New York, NY.

Siyakiya, P. (2017). The impact of institutional quality on economic performance: An empirical study of European union 28 and prospective member countries. World Journal of Applied Economics, 3(2), 3-24.

SPDC Social Policy and Development Centre. (2017). Social Development in Pakistan- Annual Review: Towards Poverty Reduction." Karachi: Social Policy and Development Centre and the Oxford University Press.

Stiglitz, J. E. (1996). Some lessons from the East Asian miracle. The World Bank Research Observer, 11, 151-177.

Tebaldi, E., \&Elmslie, B. (2013). Does institutional quality impact innovation? Evidence from crosscountry patent grant data. Applied Eco-nomics, 45(7), 887-90o.

Tabellini, G. (2005). Culture and Institutions: Economic Development in the Regions of Europe. CESIFO Working Paper no. 1492.

Ul Haq, M. (2000). Human development in South Asia 1999: The crisis of governance. Oxford University Press, USA.

Valeriani, E. and Peluso, S. (2011). The impact of institutional quality on economic growth and development: An empirical study. Journal of Knowledge Management, Economics and Information Technolo-gy,1(6), 1-25.

Vlastou, I. (2010). Forcing Africa to open up to trade: Is it worth it? The Journal of Developing 
Areas, 44, 25-39.

World Bank. (1993). The East Asian miracle: Economic growth and public policy. New York, NY: Oxford University Press.

Young, A. (1991). Learning by doing and the dynamic effects of international trade. The Quarterly Journal of Economics, 106, 369-406. 